Jurnal DIALOGIKA Manajemen dan Administrasi

Homepage: https://ejurnal.unma.ac.id/index.php/dialogika

Vol. 2 No.2 April 2021, halaman: $62 \sim 73$

E-ISSN: 2720-9865, P-ISSN: 2716-3563

DOI : https://doi.org/10.31949/dialogika.v2i02.2177

\title{
PENGARUH PENGEMBANGAN SUMBER DAYA MANUSIA DAN PENGELOLAAN DANA BOS TERHADAP MUTU PENDIDIKAN SDN SE-KECAMATAN MAJALENGKA
}

\author{
Iyus Susnardi \\ Mahasiswa Pascasarjana Universitas Majalengka, Jawa Barat, Indonesia \\ e-mail korespondensi : iyussusnardi@gmail.com
}

Disubmit Januari 2021, Diterima Maret 2021, Diterbitkan April 2021

Submitted January 2021, Accepted March 2021, Published April 2021

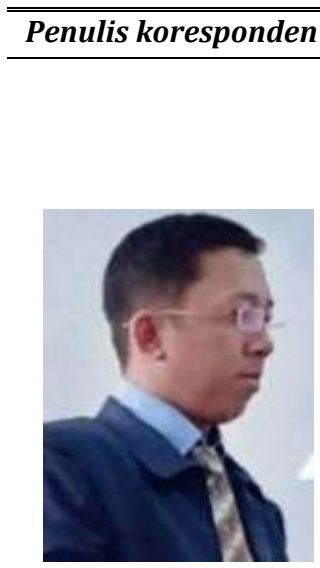

Jurnal DIALOGIKA

Manajemen dan Administrasi

diterbitkan oleh

Program Studi

Administrasi Publik

Pascasarjana

Universitas

Majalengka

\begin{abstract}
This research is motivated by the phenomenon of the low quality of education in State

Elementary Schools in Majalengka District, marked by the non-fulfillment of all applicable educational standards, aiming to determine the development of human resources; management of BOS funds and the quality of education in public elementary schools; and the influence of boss fund management and human resource development on the quality of education. The study used a quantitative approach with survey methods, data collection techniques using a questionnaire with a Likert scale distributed to 238 respondents. Processing and analyzing data using a parametric statistical approach, analyzed descriptively and verification. The results showed; Human resources and Boss Fund have been well managed and developed; Simultaneously the development of human resources and management of BOS funds have a significant effect on the quality of education with a magnitude of $74.70 \%$ and the remaining $25.30 \%$ influenced by other factors not examined. The conclusion, either partially or jointly, is that the development of human resources and the management of BOS funds affect the quality of education in Public Elementary Schools in Majalengka District.
\end{abstract}

\begin{abstract}
Keywords: HR development; Management of BOS funds, Quality of Public SD Education Abstrak Negeri se-Kecamatan Majalengka, ditandai dengan belum terpenuhinya semua standar pendidikan yang berlaku, bertujuan untuk mengetahui pengembangan sumber daya manusia; pengelolaan dana BOS dan mutu pendidikan SD Negeri; serta pengaruh pengelolaan dana bos dan pengembangan sumber daya manusia terhadap mutu pendidikan. Penelitian menggunakan pendekatan kuantitatif dengan metode survey, teknik pengumpulan data menggunakan kuesioner dengan skala likert disebarkan kepada 238 responden. Pengolahan dan analisis data menggunakan pendekatan statistik parametrik, dianalisis secara deskriptif dan verifikatif, Hasil penelitian menunjukkan ; Sumber daya manusia dan Dana Bos telah dikelola dan dikembangkan dengan baik; secara simultan pengembangan sumber daya manusia dan pengelolaan dana BOS berpengaruh signifikan terhadap mutu pendidikan dengan besaran pengaruh $74,70 \%$ dan sisanya sebesar $25,30 \%$ dipengaruhi faktor lain yang tidak diteliti. Kesimpulan, baik secara parsial maupun bersama, pengembangan sumber daya manusia dan pengelolaan dana BOS berpengaruh terhadap mutu pendidikan SD Negeri se-Kecamatan Majalengka.
\end{abstract}

Kata kunci: Pengembangan SDM; Pengelolaan dana BOS, Mutu Pendidikan SD Negeri 


\section{PENDAHULUAN}

Dalam konteks pendidikan pengertian mutu mencakup input, proses dan output pendidikan. Maka, pendidikan yang bermutu bukan sesuatu yang terjadi dengan sendirinya, melainkan merupakan hasil dari suatu proses pendidikan yang berjalan dengan baik, efektif, dan efisien (Depdiknas (2001). Secara teoretis, menurut Arcaro (2005:85), "Mutu adalah gambaran dan karakteristik menyeluruh dari barang atau jasa yang menunjukkan kemampuannya dalam memuaskan kebutuhan yang diharapkan. Dalam pendidikan, pengertian mutu mencakup input, proses dan output pendidikan". Dari dua pendapat tersebut terdapat persamaan isi utama bahwa mutu pendidikan erat kaitannya dengan "input, proses dan output".

Dengan kata lain, apabila suatu lembaga pendidikan termasuk Sekolah Dasar Negeri ingin mencapai mutu yang tinggi, upaya ke arah sana harus diawali dengan rancangan mutu input, mutu proses, dan mutu output. Salah satu langkah operasional dalam upaya merancang mutu tersebut adalah dengan ditetapkannya standar, seperti yang tercantum dalam Peraturan Pemerintah Nomor 19 Tahun 2005 tentang Standar Nasional Pendidikan yang diperbaharui melalui Peraturan Pemerintah Nomor 32 tahun 2013. Untuk menjamin ketercapaian mutu, dalam hal ini mutu pendidikan dasar dan menengah diperlukan adanya penjaminan mutu. Maka terbit Permendikbud Nomor 28 tahun 2016 tentang Sistem Pejaminan Mutu Pendidikan Dasar dan Menengah. Dalam Permendikbud tersebut dijelaskan bahwa "Penjaminan mutu pendidikan dasar dan menengah merupakan mekanisme yang sistematis, terintegrasi, dan berkelanjutan untuk memastikan bahwa seluruh proses penyelenggaraan pendidikan telah sesuai dengan standar mutu dan aturan yang ditetapkan". Mekanisme sistematis tersebut bertujuan untuk memastikan terimplementasikannya penyelenggaraan pendidikan dalam semua tahapan proses sesuai dengan standar mutu yang ditetapkan secara nasional. Implementasi dari mekanisme penjaminan mutu bertujuan untuk menjamin pemenuhan standar pada satuan pendidikan secara sistemik, holistik, dan berkelanjutan, sehingga diharapkan pada akhirnya akan tumbuh dan berkembang budaya mutu pada satuan pendidikan yang dalam penelitian ini Sekolah Dasar Negeri.

Namun demikian realita yang terjadi tiga tahun terakhir, dari hasil Evaluasi Diri Sekolah (EDS) terhadap delapan standar belum terlihat tanda-tanda pencapaian standar secara optimal, baik di tingkat nasional, tingkat provinsi, maupun kabupaten. Dari hasil telaah data yang bersumber dari Lembaga Penjaminan Mutu Pendidikan, Direktorat Jendral Pendidikan Dasar dan Menengah Kementerian Pendidikan dan Kebudayaan tentang Rapor Mutu tahun 2018 diperoleh rata-rata nilai terhadap delapan (8) Standar Nasional Pendidikan, sebagai berikut.

Tabel 1 Rapor Mutu hasil EDS SD Negeri Tahun 2018

\begin{tabular}{|c|c|c|c|}
\hline No & $\begin{array}{l}\text { Standar Nasional } \\
\text { Pendidikan }\end{array}$ & $\begin{array}{l}\text { Tingkat Prov. } \\
\text { Jawa Barat }\end{array}$ & $\begin{array}{l}\text { Tingkat } \\
\text { Nasional }\end{array}$ \\
\hline 1 & Standar Isi & $7+$ & $6+$ \\
\hline 2 & Standar Proses & 6,6 & $6+$ \\
\hline 3 & $\begin{array}{l}\text { Standar Kompetensi } \\
\text { Lulusan }\end{array}$ & $6+$ & $6+$ \\
\hline 4 & $\begin{array}{l}\text { Standar Pendidik dan } \\
\text { Tendik }\end{array}$ & $3+$ & $4+$ \\
\hline 5 & $\begin{array}{l}\text { Standar Sarana dan } \\
\text { Prasarana }\end{array}$ & $4+$ & $4+$ \\
\hline 6 & Standar Pengelolaan & $6+$ & $6+$ \\
\hline 7 & Standar Pembiayaan & $6+$ & $6+$ \\
\hline 8 & $\begin{array}{l}\text { Standar Penilaian } \\
\text { Pendidikan }\end{array}$ & $6+$ & $6+$ \\
\hline \multicolumn{2}{|c|}{ Rata-rata } & 5,59 & 5,50 \\
\hline
\end{tabular}

Berdasarkan data yang tertera pada Tabel 1, diketahui bahwa baik rata-rata provinsi $(5,59)$ maupun rata-rata nasional $(5,50)$ pencapaian delapan Standar Nasional Pendidikan belum optimal, dan diketahui pula bahwa pencapaian standar paling rendah adalah standar pendidik dan tenaga kependidikan serta standar sarana dan prasarana. Kondisi demikian, tidak jauh berbeda dengan kondisi di Kabupaten Majalengka, bahwa pemenuhan standar pendidik dan tenaga kependidikan serta pemenuhan Sarana dan Prasarana masih kurang. Dengan demikian diketahui adanya fenomena rendahnya mutu pendidikan SD Negeri se-Kecamatan Majalengka salah satunya diduga sebagai akibat rendahnya pemenuhan standar sumber daya manusia, terutama pemenuhan standar kompetensi 
guru menyangkut kemampuan (skill), sehingga dalam penelitian ini pengembangan sumber daya manusia akan dikaji sebagai variabel yang diduga mempengaruhi mutu pendidikan.

Variabel-variabel yang diduga berpengaruh terhadap peningkatan mutu pendidikan antara lain pengembangan sumber daya manusia dan pengelolaan dana BOS. Pengembangan sumber daya manusia perlu terus dilakukan, mengingat bahwa ilmu pengetahuan dan teknologi terus mengalami perubahan sejalan dengan perubahan zaman. Apalagi bagi guru sebagai pendidik, tidak boleh ketinggalan agar mampu beradaptasi dengan perubahan dan menjadi panutan bagi para peserta didik. Oleh karena itu, pengembangan sumber daya manusia akan sangat bermanfaat untuk memantapkan SDM secara individual sekaligus mensinergikan berbagai unsur dalam upaya mencapai tujuan bersama, antara lain melalui pendidikan dan pelatihan, program pendidikan lanjutan, atau kegiatan lain yang sejenis.

Almasdi (2016:17) mengemukakan bahwa "Sumber Daya Manusia adalah kekuatan daya pikir dan karya manusia yang masih tersimpan di dalam dirinya yang perlu dibina dan digali serta dikembangkan untuk dimanfaatkan sebaik-baiknya bagi kesejahteraan kehidupan masyarakat". Hal senada dikemukakan Hasibuan (2001:244) menyatakan bahwa; "Sumber daya manusia adalah kemampuan terpadu dari daya pikir dan fisik yang dimiliki individu. Sumber daya manusia dipandang sebagai kemampuan yang dimiliki manusia untuk didayagunakan untuk menjalankan suatu organisasi atau urusan sehingga berdayaguna atau berhasil guna".

Dari dua kutipan tersebut dapat disimpulkan bahwa sumber daya manusia (SDM) adalah orang yang bekerja dalam suatu organisasi yang memberikan bakat, pikiran, kreativitas dan usahanya demi kemajuan organisasi. Dalam lembaga pendidikan (sekolah) sumber daya manusia yang dimaksud adalah pendidik dan tenaga kependidikan yang harus dikembangkan terus-menerus agar mampu beradaptasi dengan perubahan lingkungan.

Dalam lembaga pendidikan formal seperti sekolah dasar, pengelolaan sumber daya manusia secara keseluruhan merupakan wewenang pemerintah pusat, sedangkan kepala sekolah sebagai pemkimpin tertinggi di sekolah hanya berwenang untuk memberdayakan dan mengembangkan. Dalam prakteknya, memberdayakan adalah menggunakan dengan cara diberi tugas untuk menjalankan proses pembelajaran sesuai dengan bidang keahliannya. Sedangkan mengembangkan sasaran utamanya adalah kompetensi atau skill. Dalam hal ini, kepala sekolah memang berwenang untuk melakukan pengembangan agar kompetensi guru dapat terus ditingkatkan sesuai tuntutan zaman.

Dari segi definisi, makna lain dari istilah pengembangan dikemukakan oleh Yuli (2005:73) yang menyatakan "Pengembangan merupakan suatu proses pendidikan jangka panjang yang mempergunakan prosedur sistematis dan terorganisir di mana pegawai manajerial mempelajari pengetahuan konseptual dan teoritis guna mencapai tujuan yang umum". Dari sudut pandang administrasi kepegawaian dalam arti luas dikemukakan Notoatmodjo (2009:2) bahwa "Secara makro, pengembangan sumber daya manusia (human resources development) adalah suatu proses peningkatan kualitas atau kemampuan manusia dalam rangka mencapai suatu tujuan pembangunan bangsa. Secara mikro, pengembangan sumber daya manusia adalah suatu proses perencanaan pendidikan, platihan dan pengelolaan tenaga atau karyawan untuk mencapai suatu hasil optimal yang dapat berupa jasa maupun benda atau uang".

Dari beberapa kutipan tentang definisi pengembangan SDM, jelaslah bahwa di dalam kegiatan pengembangan sumber daya manusia termasuk di loembaga pendidikan, terdapat suatu proses untuk meningkatkan berbagai kemampuan, baik kemampuan teoritis dan umum, maupun kemampuan teknis dan operasional pendidik untuk mempersiapkan suatu 
tanggung jawab dalam pelaksanaan tugas untuk mencapai tujuan pendidikan secara menyeluruh.

Faktor lain yang diduga berpengaruh terhadap peningkatan mutu pendidikan adalah pengelolaan keuangan. Manajemen keuangan sekolah merupakan salah satu bidang garapan substansi administrasi pendidikan yang secara khusus menangani tugas-tugas yang berkaitan dengan pengelolaan keuangan yang dimiliki dan digunakan oleh kepala sekolah.

Sulit dipungkiri bahwa sekolah sangat memerlukan anggaran pendidikan yang memadai, terutama untuk aktivitas pembangunan dan pemeliharaan gedung sekolah, pengadaan peralatan dan perlengkapan sekolah, serta pembiayaan operasional sekolah. Aktivitas-aktivitas sekolah tersebut akan terganggu apabila tidak didukung dengan anggaran pendidikan yang memadai. Semakin besar anggaran pendidikan, maka diperkirakan akan semakin meningkatkan kualitas pendidikan, dengan asumsi biaya dikelola dengan baik dan akuntabel.

Sekarang ini, salah satu sumber dana yang diandalkan untuk menunjang kelancaran penyelenggaraan pendidikan di Sekolah Dasar adalah Dana BOS.

Dana Bantuan Operasional Sekolah (BOS) adalah program pemerintah yang pada dasarnya adalah untuk penyediaan pendanaan biaya operasi non-personalia bagi satuan pendidikan dasar sebagai pelaksana program wajib belajar. Menurut Peraturan Pemerintah Nomor 48 tahun 2008 tentang pendanaan pendidikan, biaya non personalia adalah biaya untuk bahan atau peralatan pendidikan habis pakai, dan biaya tak langsung berupa daya, air, jasa, telekomunikasi, pemeliharaan sarana dan prasarana, uang lembur, transportasi, konsumsi, pajak asuransi, dan lain-lain. Penggunaan dana BOS secara garis besar dialokasikan untuk biaya operasional mencakup biaya personil dan baya nonpersonil (Dirjen Dikdasmen, 2009).

Secara operasional, penggunaan dana BOS berpedoman kepada Surat Edaran Dirjen Pajak Departemen Keuangan RI
Nomor SE-02/PJ./2006, tentang Pedoman Pelaksanaan Pemenuhan Kewajiban Perpajakan Sehubungan dengan penggunaan Dana Bantuan Operasional (BOS) oleh Bendaharawan atau Penanggungjawab Pengelolaan Penggunaan Dana BOS di masing-masing Unit Penerima BOS. Secara umum, program bantuan dana BOS bertujuan untuk meringankan beban masyarakat terhadap pembiayaan pendidikan dalam rangka program wajib belajar sembilan tahun yang bermutu.

Pembiayaan pendidikan idealnya dilakukan secara efisien. Makin efisien suatu sistem pendidikan, semakin kecil dana yang diperlukan untuk pencapaian tujuan-tujuan pendidikan. Untuk itu, bila sistem keuangan sekolah dikelola secara baik akan meningkatkan efisiensi penyelenggaraan pendidikan.

Sebenarnya pengelolaan keuangan sekolah merupakan salah satu tugas utama kepala sekolah. Keberhasilan program sekolah sangat bergantung pada cara pengelolaan dana sekolah, yang pada gilirannya mempengaruhi kinerja guru secara menyeluruh. Oleh sebab itu, kepala sekolah perlu memiliki pengetahuan yang memadai mengenai keuangan agar dapat menjadi manajer keuangan yang efekif untuk menunjang terwujudnya pendidikan yang bermutu.

Pendidikan yang bermutu secara umum dilihat dari output pendidikan, yaitu kinerja atau prestasi sekolah. Kinerja sekolah dihasilkan dari proses pendidikan. Output pendidikan dinyatakan tinggi jika prestasi sekolah tinggi dalam hal akademik, nonakademik dan prestasi lainnya seperti kinerja sekolah dan guru yang meningkat.

Menurut Mulyasa (2003:227) Dalam hal ini, terdapat lima dimensi pokok yang menentukan penyelenggaraan pendidikan bermutu, yaitu: a) Keandalan (reability), yakni kemampuan memberikan pelayanan yang dijanjikan secara tepat waktu, akurat dan memuaskan; b) Daya tangkap (responsiveness), yaitu kemauan para tenaga kependidikan untuk membantu para peserta didik dan memberikan pelayanan dengan tanggap. Proses pembelajaran hendaknya diupayakan interaktif dan 
memungkinkan para peserta didik mengembangkan kreatifitas, kapasitas, dan kapabilitas; c) Seluruh tenaga kependidikan harus benar-benar kompeten dibidangnya, reputasi penyelenggaraan pendidikan yang positif di mata msayarakat, sikap dan perilaku seluruh tenaga kependidikan mencerminkan profesionalisme dan kesopanan; d) Empati, meliputi kemudahan dalam melakukan hubungan komnukasi yang baik antar murid dan guru; dan e) Bukti langsung (tangible), meliputi fasilitas fisik, perlengkapan, tenaga kependidikan dan sarana komunikasi.

Secara yuridis, dalam sistem pendidikan nasional, perbincangan tentang mutu selalu dikaitkan dengan standar yang dapat diukur, sehingga pemerintah menerbitan Peraturan Pemerintah Nomor 19 Tahun 2005 tentang Standar Nasional Pendidikan, di dalamnya dijelaskan tentang delapan standar menyangkut aspek penting dalam proses pendidikan di sekolah.

Dengan demikian, dari telaah teori ditemukan rangkaian variabel yang saling berkaitan, yakni pengembangan sumber daya manusia, pengelolaan dana BOS, dan mutu pendidikan. Keterkaitan variabelvariabel tersebut membentuk kerangka pemikiran bahwa variabel pengembangan sumber daya manusia $\left(\mathrm{X}_{1}\right)$ berpengaruh terhadap variabel mutu pendidikan $(Y)$, variabel pengelolaan dana BOS $\left(\mathrm{X}_{2}\right)$ berpengaruh terhadap variabel mutu pendidikan (Y), kemudian variabel pengembangan sumber daya manusia dan pengelolaan dana BOS secara bersama berpengaruh terhadap mutu pendidikan (Y). Kerangka pikir dalam penelitian ini dapat digambarkan dengan paradigma penelitian sebagai berikut :

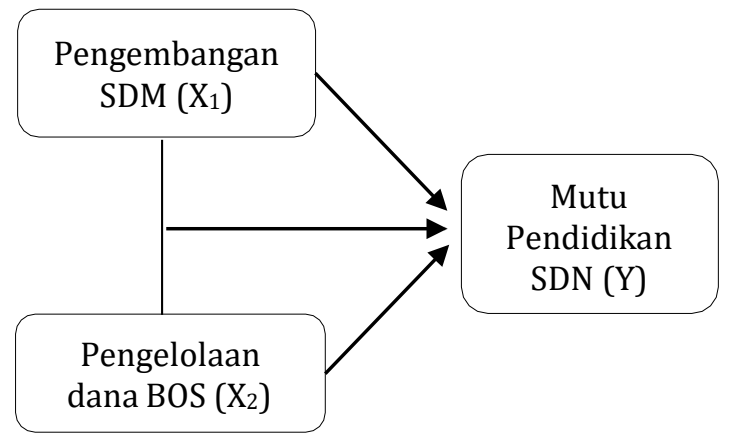

Gambar 1 Paradigma Penelitian
Berdasarkan kerangka pemikiran dan paradigma penelitian tersebut peneliti mengajukan hipotesis penelitian sebagai berikut:

1. Pengembangan sumber daya manusia SD Negeri diasumsikan baik.

2. Pengelolaan dana BOS SD Negeri diasumsikan baik.

3. Mutu pendidikan SD Negeri diasumsikan baik.

4. Terdapat pengaruh pengembangan sumber daya manusia terhadap mutu pendidikan SD Negeri.

5. Terdapat pengaruh pengelolaan dana BOS terhadap terhadap mutu pendidikan SD Negeri.

6. Terdapat pengaruh pengembangan sumber daya manusia dan pengelolaan dana BOS secara bersama terhadap mutu pendidikan SD Negeri.

\section{METODE PENELITIAN}

Metode penelitian diartikan sebagai cara ilmiah untuk mendapatkan data yang valid dengan tujuan dapat ditemukan, dikembangkan, dan dibuktikan, suatu pengetahuan tertentu sehingga dapat digunakan untuk memahami, memecahkan, dan mengantisipasi masalah. (Sugiyono, 2001) Metode penelitian yang digunakan dalam penelitian ini yaitu penelitian kuantitatif dengan analisis deskriptif dan verifikatif. Analisis deskriptif dilakukan dengan cara mencari informasi tentang gejala yang ada, kemudian didefinisikan dengan sesuai dengan tujuan. Analisis verifikatif dilakukan dengan cara mempelajari teori dan pengumpulan data melalui penyebaran kuesioner sebagai bahan untuk melakukan pengujian hipotesis.

Dalam penelitian ini peneliti ingin meneliti keterkaitan antara pengembangan sumber daya manusia dan pengelolaan dana BOS dengan mutu pendidikan SD. Adapun variabel penelitian yang akan dikaji dalam penelitian ini dibagi menjadi dua variabel utama, yaitu variabel bebas $(\mathrm{X})$ yang terdiri atas dua variabel, yaitu pengembangan sumber daya manusia $\left(\mathrm{X}_{1}\right)$ dan pengelolaan dana BOS $\left(\mathrm{X}_{2}\right)$ dan variabel terikat $(\mathrm{Y})$ yaitu mutu pendidikan SD (Y). 
Dalam penelitian ini, populasi terdiri atas guru dan kepala sekolah Dasar Negeri se-Kecamatan Majalengka sebanyak 585 orang. Penentuan jumlah sampel menggunakan rumus slovin (Umar, 2004). Dari hasil perhitungan didapat sampel sebanyak 238 orang. Pengumpulan data primer menggunakan kuesioner yang diajukan kepada responden dengan maksud mengumpulkan data langsung dari sumber utama. Dalam setiap variabel, disusun instrumen yang dijabarkan pada butir-butir kuesioner dilengkapi dengan alternatif jawaban berskala likert. Untuk menjamin validitas dan reliabilitas instrumen, dilakukan uji validitas dan reliabilitas. Data yang diperoleh diolah dan dianalisis menggunakan analisis korelasi dan regresi. Analisis dilakukan untuk mencari pengaruh variabel bebas terhadap variabel terikat. Uji hipotesis individu menggunakan uji-t, sedangkan pengujian hipotesis berganda menggunakan uji-F. Proses pengolahan data menggunakan bantuan komputer program SPSS for Window versi 20.0.

\section{HASIL PENELITIAN DAN PEMBAHASAN}

\section{Hasil Penelitian}

Data yang diperoleh dari hasil penyebaran kuesioner dianalisis secara deskriptif dan verifikatif sebagai berikut. Dalam proses analisis deskriptif, hasil jawaban responden dihitung skor masingmasing ityem dan skor kumulatif, lalu dihitung nilai persentase yang diperoleh untuk diinterpretasikan agar diperoleh nilai kualitatif dari masing-masing variabel, diperoleh hasil pengolahan sebagai berikut

Tabel 1. Rekapitulasi Data hasil jawaban responden.

\begin{tabular}{|c|c|c|c|c|}
\hline \multirow{2}{*}{ Variabel } & \multicolumn{3}{|c|}{ Skor } & \multirow{2}{*}{ Jumlah } \\
\hline & Terkecil & Terbesar & Rerata & \\
\hline $\mathrm{X} 1$ & 891 & 1035 & 971,67 & 17490 \\
\hline $\mathrm{X} 2$ & 890 & 1046 & 949,80 & \\
\hline Y & 894 & 1088 & 966,69 & Baik \\
\hline
\end{tabular}

Sumber: Hasil Penelitian, data diolah

Untuk menilai kondisi variabelvariabel penelitian secara deskriptif diperlukan acuan ilmiah,. maka setelah dilakukan melalui proses pengolahan data dengan ditemukannya skor terbesar, skor terkecil, dan rata-rata skor, hasilnya dibandingkan dengan tabel interpretasi data sebagai berikut.

Tabel 2. Interpretasi Data

\begin{tabular}{ccc}
\hline No. & Persentase & Kriteria Penilaian \\
\hline 1 & $20-35,99$ & Sangat kurang baik \\
2 & $36-51,99$ & Kurang baik \\
3 & $52-67,99$ & Cukup baik \\
4 & $68-83,99$ & Baik \\
5 & $84-100$ & Sangat baik \\
\hline
\end{tabular}

Berdasarkan hasil pengolahan data yang bersumber dari jawaban responden, diperoleh skor kumulatif, skor rata-rata, persentase dan kategori untuk masingmasing variabel sebagai berikut:

Tabel 3. Hasil Analisis Deskriptif

\begin{tabular}{lcccc}
\hline Variabel & Jumlah & Rata-rata & $\%$ & Kategori \\
\hline X1 & 17490 & 971,67 & 81,65 & Baik \\
X2 & 18996 & 949,80 & 79,82 & Baik \\
Y & 29034 & 966,69 & 81,24 & Baik \\
\hline
\end{tabular}

Sumber: Hasil Penelitian, data diolah

Berdasarkan data yang tertera pada tabel 3 dapat dijelaskan bahwa untuk variabel pengembangan sumber daya manusia memperoleh jumlah skor sebesar 17490 dengan rata-rata 971,60 atau $81,65 \%$. Untuk mengetahui makna dari besaran persentase tersebut, lalu dibandingkan dengan tabel interpretasi yang ternyata berada pada interval nilai 6883,99 yang termasuk kategori baik. Namun dari 18 butir kuesioner, terdapat skor jawaban yang terkecil yaitu tentang pendidik terbiasa melakukan penelitian tindakan kelas, artinya peneliti belum terbiasa.

Untuk variabel pengelolaan dana BOS, diperoleh jumlah skor sebesar 18996 dengan rata-rata 949,80 atau 79,82 \%. Untuk mengetahui makna dari besaran persentase tersebut lalu dibandingkan dengan tabel interpretasi yang ternyata berada pada interval nilai 68-83,99 dengan kategori baik. Namun dari 20 butir kuesioner, terdapat skor jawaban terkecil yaitu tentang tidak ada siswa miskin yang putus sekolah.

Untuk variabel mutu pendidikan SD, diperoleh jumlah skor sebesar 28034 dengan rata-rata 966,68 atau 81,24 \%. Untuk mengetahui makna dari nilai persentase tersebut lalu dibandingkan 
dengan tabel interpretasi yang ternyata berada pada interval nilai 68-83,99 dengan kategori baik. Namun dari 29 butir kuesioner terdapat jawaban yang lemah, yaitu tentang standar pengukuran sumber biaya.

Dengan demikian, semua variabel yang diteliti menurut persepsi responden berada pada kondisi baik, walaupun masih terdapat kelemahan pada aspek tertentu.

Sesuai dengan desain penelitian, selain dilakukan analisis deskriptif juga dilakukan analisis verifikatif dengan maksud untuk memverifikasi hipotesis dengan fakta hasil penelitian.

Dalam penelitian ini, analisis verifikatif dilakukan dengan tujuan untuk mengetahui pengaruh variabel bebas terhadap variabel terikat. Dalam prosesnya, data yang dikumpulkan melalui penyebaran kuesioner diolah dan dianalisis menggunakan metode statistik parametrik, dengan proses penghitungan menggunakan bantuan komputer program SPSS for window versi 20, setelah dilakukan diperoleh hasil sebagai berikut.

Pengujian validitas instrumen dengan uji-t dilakukan terhadap setiap item untuk semua variabel pengembangan sumber daya manusia, pengelolaan dana BOS, dan mutu pendidikan SD Negeri, sebagaimana tertera pada tabel 4 berikut ini.

Tabel 4, Hasil Uji Validitas.

\begin{tabular}{|c|c|c|c|c|}
\hline \multirow[t]{2}{*}{ Variabel } & \multicolumn{2}{|c|}{ r-hitung } & \multirow{2}{*}{ Sig. } & \multirow{2}{*}{ Ket. } \\
\hline & terkecil & terbesar & & \\
\hline $\begin{array}{l}\text { Pengembangan } \\
\text { SDM }\end{array}$ & 0,487 & 0,722 & 0,000 & Valid \\
\hline $\begin{array}{l}\text { Pengelolaan } \\
\text { dana BOS }\end{array}$ & 0,389 & 0,634 & 0,000 & Valid \\
\hline $\begin{array}{l}\text { Mutu Pendidikan } \\
\text { SD Negeri }\end{array}$ & 0,367 & 0,751 & 0,000 & Valid \\
\hline
\end{tabular}

Sumber: hasil Penelitian, data diolah.

Dari data yang tertera pada tabel 4 diketahui bahwa semua item untuk masingmasing variabel penelitian valid, dibuktikan dengan hasil pengujian dengan uji t, di mana semuanya t-hitung lebih besar dari t-tabel yang berarti valid.

Kemudian, dilakukan pengujian reliabilitas intrumen terhadap variabelvariabel yang diteliti dengan menggunakan metode belah dua untuk mencari nilai cronbach alpha, setelah dikerjakan diperoleh hasil sebagai berikut:

Tabel 5 Hasil Uji Reliabilitas

\begin{tabular}{lccc}
\hline Variabel & r-hitung & r-tabel & Ket. \\
\hline Pengembangan SDM & 0,867 & 0,700 & Reliabel \\
$\begin{array}{l}\text { Pengelolaan dana } \\
\text { BOS }\end{array}$ & 0,855 & 0,700 & Reliabel \\
$\begin{array}{l}\text { Mutu Pendidikan SD } \\
\text { Negeri }\end{array}$ & 0,847 & 0,700 & Reliabel \\
Sumber: Hasil Penelitian, data diolah. &
\end{tabular}

Dengan memperhatikan data yang tertera pada tabel 5, diketahui bahwa semua instrumen penelitian untuk variabel pengembangan sumber daya manusia, pengelolaan dana BOS, dan mutu pendidikan SD Negeri reliabel, dibuktikan dengan hasil pengujian dengan metode cronbach alpha, di mana t-hitung lebih besar dari t-tabel yang berarti reliabel.

Uji persyaratan analisis lainnya adalah melakukan uji normalitas data menggunakan metode kolmogorov-smirnov dengan kaidah keputusan apabila nilai yang diperoleh berada di atas $\alpha=0,05$. Berarti normal. Dari hasil pengujian diperoleh data bahwa masing-masing variabel penelitian berdistribusi normal, karena memiliki nilai di atas $\alpha=0,05$.

Setelah pengujian persyaratan analisis terpenuhi dan menunjukkan bahwa analisis dapat dilanjutkan kepada pengujian melalui statistik paramettik, maka sebelum dilakukan pengujian hipotesis terlebih dahulu dilakukan uji korelasi dan regresi dengan menggunakan bantuan komputer program SPSS for window versi 20. Dengan hasil sebagai berikut.

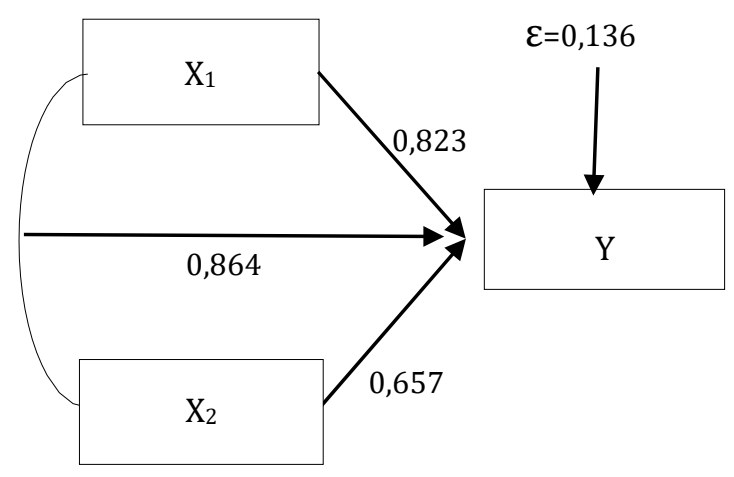

Gambar 1. Hasil Analisis Korelasi dan Regresi. 
Pengujian terpenting dalam analisis verifikatif adalah pengujian hipotesis. Dalam penelitian ini uji hipotesis secara individu menggunakan uji-t, dengan kaidah keputusan jika t-hitung $>\mathrm{t}$-tabel berati signifikan, jika sebaliknya maka tidak signifikan. Untuk hipotesis bersama atau ganda menggunakan uji-F, dengan kaidah keputusan jika $\mathrm{F}_{\text {-hitung }}>\mathrm{F}_{\text {-tabel }}$ berarti signifikan, jika sebaliknya maka tidak signifikan. Setelah dikerjakan, diperoleh hasil pengujian sebagai berikut.

Tabel 6. Hasil Pengujian Hipotesis

\begin{tabular}{lllll}
\hline Hipotesis & $(\mathrm{r})$ & $\mathrm{t}-$ Hitung & $\mathrm{t}-$ Tabel & Simpulan \\
\hline Pyx1 & 0,823 & 9,097 & 1,645 & Signifikan \\
Pyx2 & 0,657 & 6,345 & 1,645 & Signifikan \\
\hline
\end{tabular}

Sumber: Hasil pengolahan data penelitian

Dari data yang disajikan pada tabel 6 dapat diketahui bahwa hasil pengujian dengan uji-t, masing-masing $t$-hitung $>\mathrm{t}$-tabel. Hal ini dapat diartikan bahwa baik pengaruh pengembangan sumber daya manusia terhadap mutu pendidikan, maupun pengaruh pengelolaan dana BOS terhadap mutu pendidikan masing-masing berpengaruh secara signifikan.

Adapun pengujian hipotesis secara bersama, diuji dengan uji-F. Dari hasil pengujian diperoleh nilai koeffisien korelasi (r) sebesar 0,864, pengujian dengan uji-F diperoleh F-hitung sebesar 346,798 dan F-tabel dengan derajat bebas (df) 2 dan 43 pada $\alpha$ $(0,05)$ sebesar 2.650, artinya variabel pengembangan sumber daya manusia dan pengelolaan dana BOS berpengaruh signifikan terhadap mutu pendidikan SD negeri se-Kecamatan Majalengka.

Kemudian, sesuai dengan rumusan masalah yang diajukan, maka untuk mengetahui besara pengaruh variabel bebas terhadap variabel terikat, dilakukan uji determinasi dengan rumus : $\mathrm{KD}=\mathrm{r}^{2} \mathrm{x} 100$, hasilnya sebagai berikut.

Nilai koefisien korelasi (r) untuk variabel pengembangan sumber daya manusia terhadap mutu pendidikan SD Negeri se-Kecamatan Majalengka sebesar 0,823 , dengan $\mathrm{R}^{2}$ sebesar 0,6773, atau $67,73 \%$. Data ini dapat diartikan bahwa pengembangan sumber daya manusia berpengaruh terhadap mutu pendidikan sebesar $67,73 \%$.

Nilai koefisien korelasi (r) variabel pengelolaan dana BOS terhadap mutu pendidikan SD Negeri se-Kecamatan Majalengka sebesar 0,657, dengan $\mathrm{R}^{2}$ sebesar 0,4316, atau 43,16\%. Data ini dapat diartikan bahwa pengelolaan dana BOS berpengaruh terhadap mutu pendidikan SD Negeri se-Kecamatan Majalengka sebesar 43,16 .

Nilai koefisien korelasi (r) untuk variabel pengembangan sumber daya manusia dan pengelolaan dana BOS terhadap mutu pendidikan SD Negeri seKecamatan Majalengka secara bersama sebesar 0,864 dengan $\mathrm{R}^{2}$ sebesar 0.7470 atau $74,70 \%$. Hal ini berarti keragaman mutu pendidikan SD Negeri se-Kecamatan Majalengka disebabkan oleh keragaman pengembangan sumber daya manusia dan pengelolaan dana BOS sebesar 74,70\%, sedangkan siasanya $25,30 \%$ disebabkan faktor lain yang tidak dimasukan ke dalam model penelitian ini.

Selanjutnya, dalam analisis verifikatif ini dilakukan juga uji sensitivitas, kegunaannya untuk mengetahui tingkat sensitivitas dari variabel pengembangan sumber daya manusia dan pengelolaan dana BOS terhadap perubahan yang terjadi pada variabel bebas (mutu pendidikan), maka diuji dengan menghitug nilai Beta Coefficient, dengan hasil sebagai berikut.

Tabel 7. Nilai Beta Coefficient

\begin{tabular}{clc}
\hline No. & \multicolumn{1}{c}{ Variabel } & $\begin{array}{c}\text { Nilai Beta } \\
\text { Coefficient }\end{array}$ \\
\hline 1. & $\begin{array}{l}\text { Pengembangan sumber } \\
\text { daya manusia }\end{array}$ & 0.816 \\
2. & Pengelollaan dana BOS & 0.564 \\
\hline
\end{tabular}

Sumber: Hasil pengolaha data penelitian

Dari nilai yang tertera pada tabel 7 , dapat dijelaskan bahwa : a) Setiap kenaikan satu standard deviasi dari variabel pengembangan sumber daya manusia akan meningkatkan 0,816 standard deviasi variabel murtu pendidikan; b) Setiap kenaikan satu standard deviasi dari variabel pengelolaan dana BOS akan meningkatkan 0.564 standard deviasi variabel mutu pendidikan. Dengan demkian, dari hasil uji 
beta coefficients tersebut diketahui bahwa variabel mutu pendidikan lebih sensitive terhadap perubahan yang terjadi pada variabel pengembangan sumber daya manusia, karena nilai beta yang dimiliki lebih besar dibandingkan dengan nilai beta variabel pengelolaan dana BOS.

\section{Pembahasan}

Berdasarkan paparan hasil jawaban responden mengenai pengembangan sumber daya manusia secara umum pengembangan sumber daya manusia telah dilaksanakan dengan baik sesuai dengan tuntutan dan kebijakan yang berlaku. Hal ini mengindikasikan bahwa pada umumnya responden memberikan tanggapan positif terhadap pengembangan sumber daya manusia di SD. Dalam hal ini, para kepala sekolah telah menjalankan kemampuan manajerialnya yang dibuktikan dengan diperolehnya persentase rata-rata skor sebesar $81,65 \%$, paling tinggi sebesar $86,97 \%$ berkenaan dengan pelaksanaan pengembangan sumber daya manusia yang senantiasa mendorong keterlibatan warga sekolah (pendidik) untuk mengembangkan diri dengan cara belajar secara mandiri, baik melalui buku, media massa dan sumber lain yang tersedia. Sedangkan nilai persentase yang paling rendah sebesar $74,87 \%$ tentang pengembangan sumber daya manusia yang berkaitan dengan kebiasaan guru dalam melakukan penelitian tindfakan kelas yang merupakan temuan empiris untuk variabel pengembangan sumber daya manusia di SD. Artinya, dalam mengembangkan sumber daya manusia, kepala sekolah SD masih terdapat kelemahan berkenaan dengan upaya peningkatan profesionalisme guru melalui pelaksanaan pembiasaan melakukan penelitian tindakan kelas.

Dari hasil wawancara dengan kepala sekolah, pengawas, dan beberapa orang guru, diperoleh informasi bahwa pada dasarnya sependapat tentang hasil penelitian ini. Berkenaan dengan fenomena yang berkembang, tentang kewenangan dalam mengembangkan sumber daya manusia di Sekolah Dasar, yang paling dominan ada pada kewenangan kepala sekolah masing-masing. Namun ada juga yang berpendapat bahwa secara mandiri, masing-masing guru memiliki kewajiban dalam mengembangkan dirinya sebagai tuntutan kerja secara profesional, Hanya memang, akan lebih baik dan terarah jika dikelola oleh kepala sekolah yang memiliki kewenangan sebagai manajer sumber daya manusia.

Di masa reformasi pendidikan pengelolaan dana BOS menjadi topik yang banyak diperbincangkan, baik oleh guru maupun masyarakat karena erat kaitannya dengan visi misi pemerintah yang bercitacita untuk mencerdaskan bangsa berdasarkan amanat Undang-undang. Dalam hal ini, pengelolaan dana BOS yang dimaksud adalah kewajiban kepala sekolah dalam memanfaatkan Dana BOS untuk menjaga kesinambungan penyelenggaraan pendidikan dalam upaya memberikan pelayanan kepada masyarakat. Landasan teori tentang pengelolaan dana BOS diambil dari kebijakan yang berlaku, yakni tentang petunjuk teknis pengelolaan Dana BOS yang dinamis, yang kadang-kadang setiap tahun terdapat perbedaan walaupun tidak terlalu kelihatan.

Pada observasi awal ditemukan fenomena bahwa pengelolaan dana BOS masih rendah. Hal ini memerlukan penjelasan yang dapat mengungkap fakta yang sebenarnya. Maka dilakukanlah penelitian, untuk memperoleh kejelasan tentang pengelolaan dana BOS dimaksud dengan cara menyebarkan kuesioner untuk memperoleh data yang relevan. Setelah diperoleh data, data tersebut diproses dan dianalisis secara cermat. Dari proses tersebut, diperoleh hasil jawaban responden atas kuesioner yang disebarkan menunjukkan bahwa rata-rata pengelolaan dana BOS SD berada dalam katagori baik, karena nilai rata-rata persentase jawaban responden sebesar 79,82\%. Namun demikian, dari dua puluh indikator yang diajukan kepada responden, jawabannya memang bervariasi.

Indikator dengan nilai persentase tertinggi ada pada aspek mekanisme pengelolaan Dana BOS SD terdapat penentuan sekolah penerima dana" sebesar 87,89\% Artinya, dalam pengelolaan Dana 
BOS, telah terdapat mekanisme yang jelas sesuai aturan. Hal ini dapat menjelaskan bahwa pada saat dilakukan observasi awal terdapat fenomena bahwa pengelolaan dana BOS SD Negeri masih rendah, ternyata dari hasil penelitian tidak sepenuhnya demikian. Artinya pengelolaan dana BOS SD Negeri secara umum dapat dikatakan baik, namun memang belum sepenuhnya terpenuhi dengan baik karena masih terdapat kelemahan pada indikator tertentu. Dari hasil analisis deskriptif diketahui adanya indikator dengan nilai persentase terendah menurut persepsi responden, yaitu indikator Nomor 18, yaitu "Dengan adanya dana BOS SD, tidak ada siswa miskin yang putus sekolah, hanya sebesar $74,78 \%$.

Dengan demikian, pengelolaan dana BOS SD masih memiliki kelemahan dalam hal memberi jaminan bahwa tidak ada lagi siswa miskin yang tidak putus sekolah. Persepsi responden menyatakan belum sepenuhnya demikian, karena memang dana BOS bukan satu-satunya penentu keberlangsungan anak untuk sekolah, dalam arti masih banyak faktor lain yang mempengaruhinya.

Dilihat dari keseluruhan sistem pendidikan, keberhasilan dalam mewujudkan tingkat ketercapaian tujuan pendidikan yang bermutu tercermin dari mutu pembelajaran di sekolah, karena inti dari proses pendidikan terdapat dalam interaksi peserta didik dengan pendidik pada saat proses pembelajaran berlangsung. Tetapi, berdasarkan kebijakan yang berlaku saat ini, pengukuran mutu pendidikan tidak hanya dilihat dari mutu pembelajaran, melainkan dilihat dari ketercapaian seluruh standar yang telah diaturtoleh kebijakan, yakni ketercapaian delapan standar. Dengan kata lain, jika delapan standar tersebut telah tercapai optimal, berarti pendidikan di SD dapat dikatakan bermutu, jika sebaliknya berarti mutu pendidikan masih rendah.

Pada awal proses penelitian, peneliti menemukan adanya fenomena bahwa mutu pendidikan SD masih rendah. Hal ini pula yang membuat peneliti merasa tertarik untuk meneliti lebih mendalam, karena rendahnya mutu pendidikan merupakan indikator lemahnya sistem pendidikan, khususnya di SD. Maka, peneliti melakukan penelitian dengan mengungkap indikatorindikator terkait mutu pendidikan, antara lain berkenaan dengan aspek-aspek inti yang ada pada setiap standar sebagaimana dijelaskan pada Peraturan Pemerintah Nomor 19 tahun 2005 tentang Standar Nasional Pendidikan.

Setelah dilakukan penelitian diperoleh sejumlah data tentang mutu pendidikan SD Negeri dan telah diproses serta dianalisis secara cermat. Kemudian ditemukan data sebagai informasi akurat untuk menjelaskan fenomena. Dari proses tersebut, diperoleh hasil jawaban responden atas kuesioner yang disebarkan menunjukkan bahwa rata-rata mutu pendidikan SD berada dalam katagori baik, karena nilai rata-rata persentase jawaban responden sebesar $81,24 \%$. Namun dari dua puluh sembilan indikator yang diajukan kepada responden, jawabannya memang bervariasi.

Indikator dengan nilai persentase tertinggi terdapat pada aspek pencapaian strandar pendidik dan tenaga kependidikan dilihat dari terpenuhinya kualifikasi akademik minimal S-1.", sebesar 91,43\% Artinya, mutu pendidikan SD Negeri dilihat dari standar kualifikasi akademik dan kompetensi guru telah terpenuhi dengan baik, guru hampir semua telah memenuhi standar (S-1). Apabila pada observasi awal dilihat secara keseluruhan, terdapat kelemahan dalam mutu pendidikan SD yang merupakan fenomena menarik untuk diteliti, ternyata setelah dilakukan penelitian terjawab bahwa tidak semua aspek lemah, terbukti menurut persepsi responden terdapat indikator yang berada pada kategori sangat baik.

Dengan demikian dapat dikatakan bahwa mutu pendidikan secara umum dapat dikatakan baik, namun memang belum sepenuhnya baik karena masih terdapat kelemahan pada indikator tertentu. Dari hasil analisis deskriptif diketahui adanya indikator dengan nilai persentase terendah menurut persepsi responden, yaitu indikator Nomor 24, yaitu "yaitu "Pencapaian strandar pembiayaan diukur dari keberadaan sumber biaya" 
hanya sebesar 75,13\%. Artinya, kelemahan mutu pendidikan tidak mencakup keseluruhan, melainkan hanya lemah pada sebagian saja.

\section{PENUTUP}

Berdasarkan penelitian serta pengolahan dan analisis data baik secara deskriptif maupun verifikatif, dapat disimpulkan sebagai berikut.

Dari hasil analisis deskriptif, diperoleh kesimpulan :

1. Sumber daya manusia (guru) SD menurut persepsi responden telah dikembangkan dengan baik, namun masih terdapat kelemahan pada aspek kebiasaan melakukan tindakan kelas.

2. Dana BOS SD Negeri menurut persepsi responden telah dikelola dengan baik, namun masih terdapat kelemahan pada aspek siswa miskin yang putus sekolah.

3. Mutu pendidikan SD Negeri menurut persepsi responden telah mencapai kondisi baik, namun masih terdapat kelemahan pada aspek pengukuran standar pembiayaan yang kurang mempertimbangkan sumber biaya.

Dari hasil analisis verifikatif diperoleh kesimpulan sebagai berikut:

1. Pengembangan sumber daya manusia secara parsial berpengaruh terhadap mutu pendidikan SD Negeri dengan besaran pengaruh $67,73 \%$, dibuktikan dengan hasil uji hipotesis yang signfikan.

2. Pengelolaan dana BOS secara parsial berpengaruh terhadap mutu pendidikan SD Negeri dengan besaran pengaruh $43,16 \%$, dibuktikan dengan hasil uji hipotesis yang signifikan.

3. Pengembangan sumber daya manusia dan pengelolaan dana BOS secara bersama berpengaruh terhadap mutu pendidikan SD Negeri dengan besaran pengaruh $74,70 \%$, sisanya sebesar $25,30 \%$ dipengaruhi oleh faktor lain yang tidak diteliti. Tingkat signifikansi dibuktikan dengan hasil uji hipotesis yang menunjukkan bahwa nilai F-hitung lebih besar dari F-tabel.

\section{DAFTAR PUSTAKA}

Ali M. (2011). Memahami Riset Prilaku dan Sosial. Bandung: CV. Pustaka.
Anwar Prabu Mangkunegara. (2013). Manajemen Sumber Daya Manusia. Perusahaan. Bandung: PT. Remaja Rosdakarya.

Arbangi. (2018). Manajemen Mutu Pendidikan, Depok: Prenadamedia Group.

Arikunto, Suharsimi. (2006). Prosedur Penelitian suatu Pendekatan Praktik, Jakarta: PT. Asdi Mahasatya.

Arcaro, Joremo S, (2005). Pendidikan Berbasis Mutu, Prinsip Prinsip Perumusan dan Langkah Penerapan, Jakarta: Penerbit Riene Cipta.

Almasdi Yunus Suit, (2006). Aspek Sikap Mental Dalam Manajemen Sumber Daya Manusia Indonesia, Jakarta: Ghalia Indonesia

Bagastawa (2006). Sistem Sumber Daya Manusia, New York: Oxford University Press. Inc.

Depdiknas. (2001). Manajemen Pendidkan Mutu Berbasis Sekolah, Jakarta: Depdiknas.

De Cenzo \& Robbin, (1999). Human Resource Management, Sixty Edition, New York. John Willey \&Son.Inc.

Hamriani. (2014). Manajemen Sumber Daya Manusia. Makassar: Alauddin University Press.

Krismiati (2017). Pengembangan Sumber Daya Manusia dalam Meningkatan Kualitas Pendidikan di SD Negeri Inpres Angaswa Biak, Jurnal Office, Volume 3 Nomor 2, halaman 43-50.

Komariah, Aan dan Engkoswara. (2012). Andministrasi Pendidikan Cet, III, Bandung: Alfabeta.

Luther M.Gulick (1965). Educational Administration, Edition, New York, McGraw-Hill.co.

Mangkunegara (2013). Manajemen Sumber Daya Manusia Perusahaan, Bandung : PT Remaja Rosdakarya.

Mulyasa, E. (2003). Menjadi kepala Sekolah Profesional Dalam Konteks Menyukseskan MBS dan KBK (Bandung: PT Remaja Rosada Karya. (2016). Manajemen Berbasis Sekolah: Konsep, Strategi dan Implementasi. Bandung: Remaja Rosda Karya. 
Nawawi, Hadari (2000). Metode Penelitian Bidamg Sosial. Yogyakarta: Gadjah Mada University Press.

Notoatmojo, Soekidjo. (2009). Pengembangan Sumber Daya Manusia. Jakarta: Rineka Cipta.

Riduwan. (2013), Skala Pengukuran Variabel-variabel Penelitian, Bandung: Penerbit Alfabeta.

Sadiman, Arief.S dkk. (2009). Media Pendidikan; Pengertian, Pengembangan, Pemanfaatannya, Jakarta: PT Raja Grafindo Persada.

Sastradipoera, Komaruddin. (2002). Strategi Pembangunan Sumber Daya Berbasis Pendidikan Kebudayaan, Bandung : Kappa Sigma.

Stephen P. Robbins \& Mary Coulter. (1999) . (terj. T. Hermya), Management, sixth Edition, Jakarta: PT. Indojaya Multitama.

Subagyo. (2004). Statistik Terapan Dalam Penelitian Ilmu-Ilmu Sosial dan Pendidikan. Jakarta : Rineka Cipta.

Sugiyono. (2011). Metode Penelitian Kuantitatif \& Kualitatif. Bandung : Alfabeta.

Syukur, Fatah. (2015). Manajemen Sumber Daya Manusia Pendidikan, Semarang: Pustaka Rizki Putra.

Terry, George R.,(2000). Prinsip-Prinsip Manajemen. (edisi bahasa Indonesia), Bandung: PT. Bumi Aksara.

Tuti Munfaridhah. (2008). Implementasi Sumber Daya Manusia. Tesis. Yogyakarta: UIN Sunan Kalijaga.
Tilaar, H.A.R. dan Nugroho, Riant. (2008). Kebijakan Pendidikan. Yogyakarta, Pustaka Pelajar.

Umar, Husen, (2004). Riset Sumber Daya Manusia dalam Organisasi, Jakarta PT Gramedia.

Winardi (2004). Manajemen Perilaku Organisasi, Jakarta: Kencana Prenada Media Group.

Wherther, William B and Keith Davis, (2003). Human Resourches And Personal Management, International Edition. McGraw-Hill, Inc.USA.

Yuli Sri Budi Cantika (2005). Manajemen Sumber Daya Manusia, Jakarta: Penerbit Mandar Maju.

Permendikbud Nomor 28 Tahun 2016 tentang Sistem Penjaminan Mutu Pendidikan Dasar dan Menengah.

Permendiknas Nomor 16 Tahun 2007 tentang Standar Kualifikasi Akademik dan Kompetensi Guru.

Peraturan Pemerintah Nomor 19 Tahun 2005 tentang Standar Nasional Pendidikan.

Peraturan Pemerintah Nomor 32 Tahun 2013 tentang Perubahan atas Peraturan Pemerintah Nomor 19 Tahun 2005 tentang Standar Nasional Pendidikan.

Surat Edaran Dirjen Pajak Departemen Keuangan RI Nomor SE-02/PJ./2006, tentang Pedoman Pelaksanaan Pemenuhan Kewajiban Perpajakan.

\section{BIOGRAFI PENULIS}

\begin{tabular}{l} 
Enus Susnardi Mahasiswa Program Studi Manajemen Pendidikan Islam Pascasarjana \\
Eniversitas Majalengka., Jawa Barat, Indonesia. \\
\hline
\end{tabular}

